\title{
INFLUENCE OF THE PILE STIFFNESS ON THE GROUND SLAB BEHAVIOUR
}

\author{
Kęstutis URBONAS ${ }^{\mathrm{a}}$, Danute SLIŽYTE் ${ }^{\mathrm{b}}$, Rimantas MACKEVIČIUS ${ }^{\mathrm{b}}$ \\ ${ }^{a}$ Department of Steel and Timber Structures, Faculty of Civil Engineering, Vilnius Gediminas Technical \\ University, Sauletekio al. 11, LT-10223, Vilnius, Lithuania \\ ${ }^{b}$ Department of Geotechnical Engineering, Faculty of Civil Engineering, Vilnius Gediminas Technical University, \\ Sauletekio al. 11, LT-10223, Vilnius, Lithuania
}

Received 12 Dec 2015; accepted 30 Mar 2016

\begin{abstract}
Just as other structural elements, ground slabs are an important unit of a building. It is especially true in the case of buildings, such as logistic centres, for which the primary purpose is storage of various goods. In this kind of buildings, floor slabs usually have high loads. For buildings where truck lifts are used, there are special requirements for flatness tolerance across and along the driving track of truck lifts. Therefore, the floor settlement differences in selected distances are limited. In localities where the soils under the floor slab are weak, they should be replaced or compacted. If these solutions are not possible or economically inappropriate, the slabs have to be supported on piles that must be based on strong deep soils. During the design process, it is very important to assign a proper value of rigidity of the piles. Pile stiffness has an enormous influence on the settlement of the slab as well as on the reinforcement intensity of the slab or even on the slab thickness. This paper presents the methodology for the evaluation of pile stiffness. In addition, it provides recommendations for the calculation of the floor slab on the piles. Calculations and obtained results confirmed the importance of certain design stages.
\end{abstract}

Keywords: stiffness coefficient, piles, settlements of a pile, RC ground slab on piles, reinforcement of the ground slab, flatness requirements.

\section{Introduction}

When designing a monolithic reinforced concrete plate on the ground, its behaviour is determined by the characteristics of the soil under the plate. In places where the floor plate is on a weak and deformable ground, the soil must be replaced or compacted. Usually, the upper base layer is compacted. If these solutions are impossible and economically unfeasible, floor plates can be installed on piles, which transmit the load to deeper soil layers by side friction and base. Plates on piles work affects both structural element stiffness, interconnection type and stiffness, load distribution and intensity, etc. (Lee et al. 2015). It is particularly important to conduct a proper assessment of the pile stiffness during the plate design. In such a task, the accuracy of calculations depends on the accuracy of soil characteristics and the evaluation of the interaction of the piles and pile installation technologies. The work of pile ground and pile behaviour can be modelled by FEM and BEM (Comodromos et al. 2009; Concrete Society 2003; Gusev, Tashkinov 2012; Mendonça, Paiva 2003), side friction and basis modelling support with springs (Ripunjoy 2014; Fioravante 2002; Samofalov et al. 2015) instead of the pile plate in the model to put an elastically ductile or elastic spring support (Ripunjoy 2014; Fioravante 2002; Samofalov et al. 2015). Some of the methods are useful only for preliminary design or for checking purposes, while others are capable of giving detailed performance predictions and can be used for detailed design (Technical Committee TC18 on Piled Foundations 2001). The disadvantage of the first three methods is a lot of time required for calculations (Ripunjoy 2014; Gusev, Tashkinov 2012; Mendonça, Paiva 2003; Wulandari, Tjandra 2015) and the need for special calculation programs.

Load size and layout can be very diverse and, usually, not very precisely defined. Therefore, after setting out the pile under the plate, the aim is to ensure that all middle and edge piles take over the load from the same floor area and the settlement is similar.

Such a task of the floor plate design consists of several components: the pile stiffness calculation, pile layout, selection of the floor plate thickness, reinforcement type and eligibility of calculations of floor plate settlements (Samofalov et al. 2015; Basile 2015; Poulos 2001). According to the results of the numerical analysis, the

Corresponding author: Kęstutis Urbonas

E-mail: kestutis.urbonas@vgtu.lt 
existence of the raft does not affect the vertical stiffness of the pile head, if loadings less than the allowable load.

This paper examines the pile stiffness, its detecting possibilities from data of the pile static tests and stiffness prediction when static tests of the piles are not performed (Jeong, Cho 2014). An idealized model of the plate on piles was chosen, stating that when there is no direct contact between the soil and the plate, piles do not affect each other.

The objective of the study was to suggest an algorithm to evaluate the stiffness of the pile by calculating deformations and reinforcements of the panels in accordance with regulatory requirements.

\section{Background of the analysis}

The design process for plates on piles can be considered as a three-stage process (Poulos 2001):

- a preliminary stage, when the effects of the number of piles on load capacity and settlement are assessed via an approximate analysis;

- a more detailed examination to assess where piles are required and to obtain some indication of the piling requirements;

- a detailed design phase, in which a more refined analysis is employed to confirm the optimum number and location of the piles, and to obtain essential information for the structural design of the foundation system.

An approximate method is based on the elastic theory and interactions between the components of the piled plate. Poulos (1994) modelled a piled raft in the form of a plate supported by springs representing piles. In a system of a plate on piles, four interactions (Basile 2015) can be observed: pile-soil, pile-pile, plate-soil, and pile-plate. The contribution of the plate is practically negligible in this particular case of very compressible surface soil material (Comodromos et al. 2009). As pile spacing increases, the load proportion of piles becomes higher and pilepile interaction decreases (Lee et al. 2015). Therefore, the impact of ground under the plate and the interaction between piles are not considered in this article, as only piles are evaluated by introducing springs (Fig. 1).

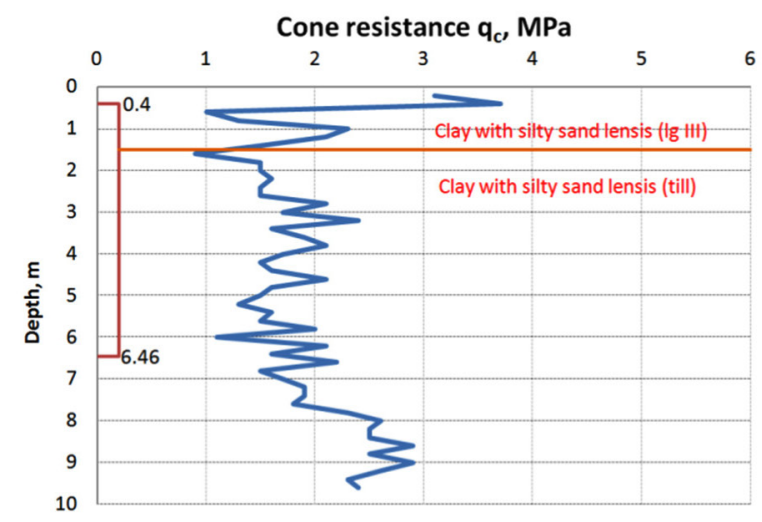

b)

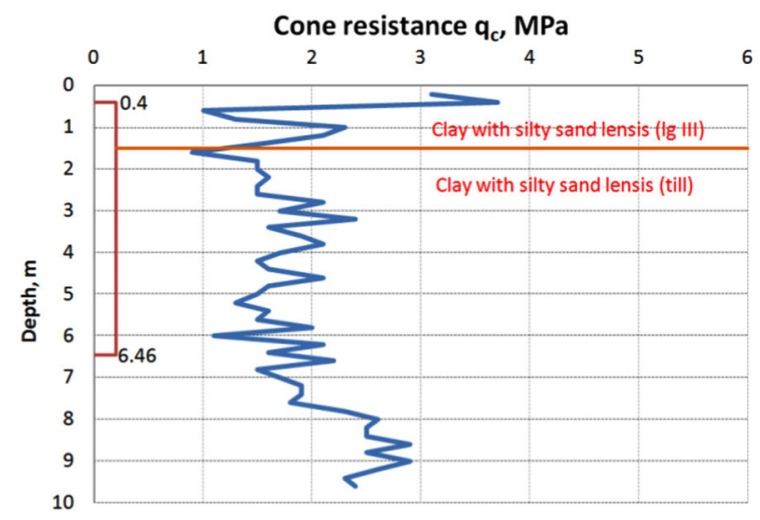

Fig. 2. Cone penetration test and borehole data: $a-$ near the $1^{\text {st }}$ test pile, $b-$ near the $2^{\text {nd }}$ test pile 


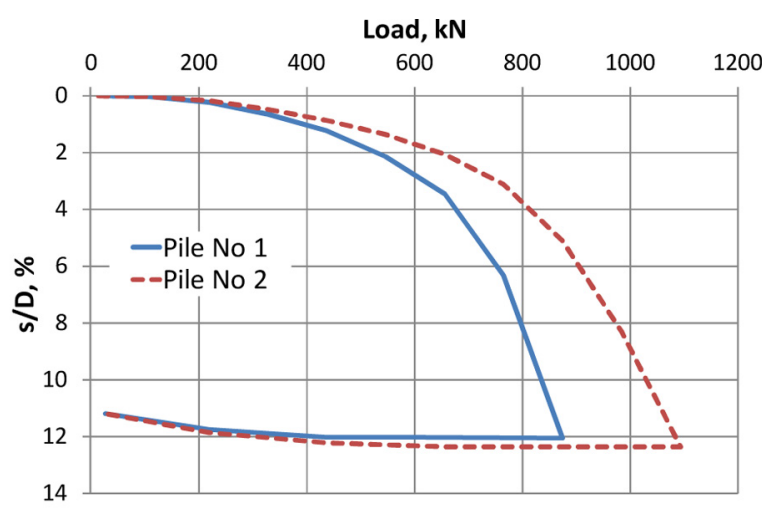

Fig. 3. Results of the pile static load test

Table 1. Data on piles and static load tests

\begin{tabular}{c|c|c|c|c|c|c}
\hline $\begin{array}{c}\text { Pile } \\
\text { No. }\end{array}$ & $\begin{array}{c}\text { Diameter, } \\
D \mathrm{~mm}\end{array}$ & $\begin{array}{c}\text { Length, } \\
\mathrm{m}\end{array}$ & $\begin{array}{c}R_{\text {cmax }}, \\
\mathrm{kN}\end{array}$ & $\begin{array}{c}s / D, \\
\%\end{array}$ & $\begin{array}{c}R_{\text {cau, ultimate }} \\
\text { load, } \mathrm{kN}\end{array}$ & $\begin{array}{c}R_{\text {conv }} \\
\mathrm{kN}\end{array}$ \\
\hline 1 & 380 & 5.94 & 875 & 12.06 & 975 & 835 \\
2 & 380 & 8.13 & 1093 & 12.36 & 1193 & 1029 \\
\hline
\end{tabular}

According to Eurocode 7 (EN 1997-1:2004), when piles are used to reduce the settlement of a raft, their resistance corresponding to the creep load may be used in analysing the serviceability states of the structure. This advice obviously concerns piled rafts, where the piles act as settlement reducers (Katzenbach et al. 2000). The pile yield resistance $R_{y}$ can be defined as the load beyond which the rate of axial pile displacement under constant load takes place with a notably increased increment. The yield resistance is deduced by analytical or graphical means as the point of maximum curvature of the curve giving the factor $\alpha_{y}$ as a function of load.

For testing pile yield resistance (Fig. 4) as the point of the maximum curvature $R_{y}$ :

- the $1^{\text {st }}$ pile $-538.2 \mathrm{kN}$, when $s_{y} / D$ is $2.08 \%$ or the settlement amounts to $7.90 \mathrm{~mm}$;

- the $2^{\text {nd }}$ pile $-665.9 \mathrm{kN}$, when $s_{y} / D$ is $2.15 \%$ or the settlement amounts to $8.17 \mathrm{~mm}$.

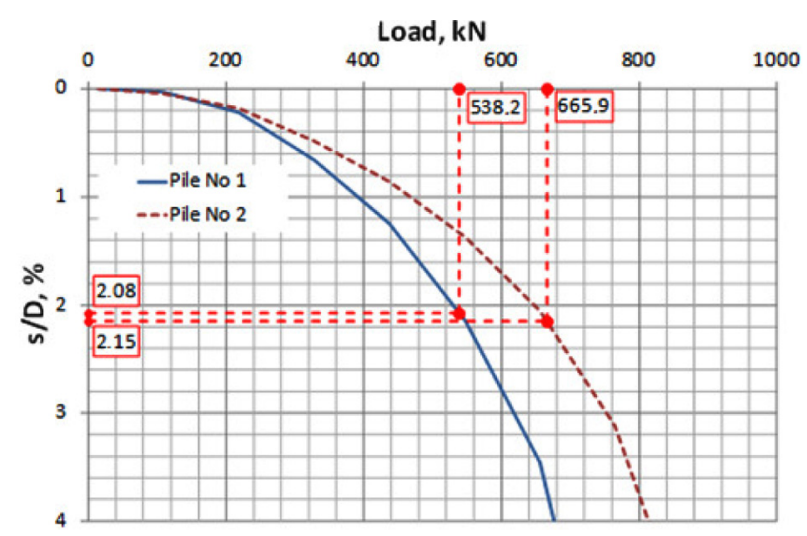

Fig. 4. Yield resistance $R_{y}$ and $s_{y} / D$ from the static load test

\subsection{Spring stiffness estimation from the pile static load test}

For one of the springs that model pile work, the method for the determination of the stiffness coefficient is its direct calculation from the pile test:

$$
k_{s}=\frac{F_{s f}}{s},
$$

where $s$ is pile settlement, $F_{s f}$ - the "safe load" multiplied by 1.5 , the "safe load" being the load derived by applying a factor of safety on the ultimate load capacity of the pile or as it is determined from a load test (IS 29111-4 2010). It can be considered as pile yield resistance $R_{y}$.

This methodology of getting the stiffness coefficients of the two piles at the maximum, minimum and average for settlements is presented in Tables 2 and 3 .

Table 2. Pile stiffness from the static load test

\begin{tabular}{c|c|c|c}
\hline \multirow{2}{*}{ Pile No. } & \multicolumn{3}{|c}{$k_{s} \mathrm{MN} / \mathrm{m}$} \\
\cline { 2 - 4 } & $\begin{array}{c}\text { Secant 1, } \\
s=8 \mathrm{~mm}\end{array}$ & $\begin{array}{c}\text { Secant 2, } \\
s=10 \mathrm{~mm}\end{array}$ & $\begin{array}{c}\text { Secant 3, } \\
s=12 \mathrm{~mm}\end{array}$ \\
\hline 1 & 100.92 & 80.73 & 67.28 \\
2 & 124.86 & 99.89 & 83.24 \\
\hline
\end{tabular}

Table 3. Secant passes through the test curve

\begin{tabular}{c|c|c|c}
\hline \multirow{2}{*}{ Pile No. } & \multicolumn{3}{|c}{$\begin{array}{c}\text { Settlement/load, due to which a secant passes } \\
\text { through the test curve, } \mathrm{mm} / \mathrm{kN}\end{array}$} \\
\cline { 2 - 4 } & $s=8 \mathrm{~mm}$ & $s=10 \mathrm{~mm}$ & $s=12 \mathrm{~mm}$ \\
\hline 1 & $3.93 / 397.2$ & $5.86 / 472.8$ & $8.12 / 544.9$ \\
2 & $3.70 / 462.6$ & $5.64 / 563.9$ & $7.90 / 658.6$ \\
\hline
\end{tabular}

The stiffness coefficient corresponding to secants is shown in Figure 5.

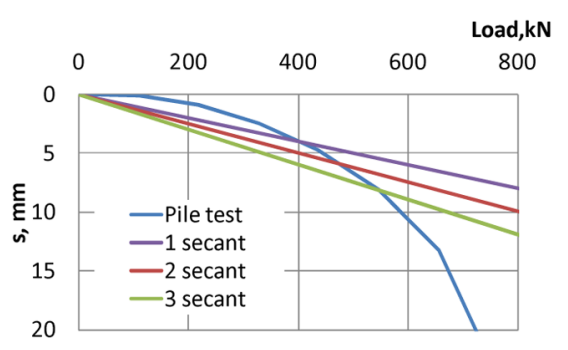

Fig. 5. Static load test curve of the pile stiffness coefficient versus the $1^{\text {st }}$ pile

\subsection{Spring stiffness estimation from the pile static load test - the Weibull curve}

This method is suitable in cases where the test has not determined the yield resistance and factor $\alpha_{y}$. The load - the normalized settlement curve is fit to the Weibull curve:

$$
\frac{R}{R_{u}}=1-\exp \left\{-\left[\frac{s / D}{s_{y} / D}\right]^{m}\right\}
$$


where $R$ is loading at pile head $\mathrm{kN} ; R_{u}$ - ultimate pile bearing capacity (or asymptotic ultimate bearing resistance $R_{\text {cau }}$ values) kN; $s$ - displacement at pile head mm; $s_{y}$ - displacement at yield point; $D$ - pile diameter; $m-$ displacement index. The magnitude of the ultimate pile bearing capacity and displacement are shown in Figure 6 .

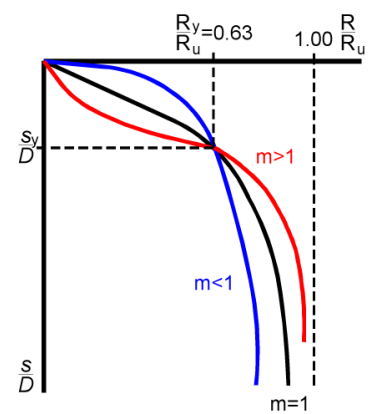

Fig. 6. Variable definitions of the Weibull curve (Takagi et al. 2007)

This curve always passes the same yield point at $R_{y} /$ $R_{u}$ of 0.63 , the shape parameter $m$ controls the shape of the curve (Fig. 6). Experiments show that when the load on the top of the pile $R<(0.5 \sim 0.6) R_{u^{*}}$ ( $R_{u}$. is the ultimate load), the settlement increases linearly within the increase of the load, and the stiffness remains approximately at a constant value (Cheng 2011).

In our case, $m$ and $s_{y} / D$ indicators that describe the curve are presented in Table 4. They are typical to nondisplacement piles supported by friction (Takagi et al. 2007).

Table 4. Parameters of curves

\begin{tabular}{c|c|c|c|c}
\hline Pile No. & $m$ & $s_{y} / D$ & $R_{\text {cau }}, \mathrm{kN}$ & $R_{y}, \mathrm{kN}$ \\
\hline 1 & 0.594 & 2.960 & 975 & 614 \\
2 & 0.595 & 2.985 & 1193 & 752 \\
\hline
\end{tabular}

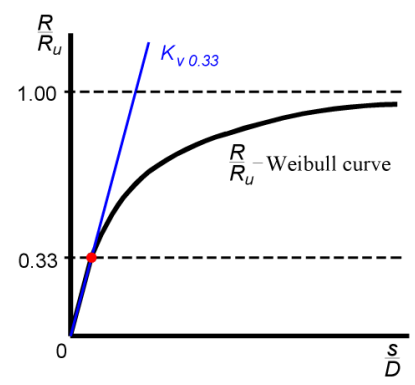

Fig. 7. Determination of $K_{v 0.33}$ using the Weibull curve

The resulting Weibull curve is plotted on normalized axes. A secant is drawn through the point, where the coordinates are $(0,0)$, and the point of the curve, where $R / R_{u}=0.33$. The resulting dimensionless pile stiffness $K_{v 0.33}$ :

$$
K_{v 0.33}=0.33 /(s / D)
$$

where $s / D$ is normalised pile settlement when $R / R_{u}=0.33$ (Fig. 7).

Because $K_{v 0.33}$ is a dimensionless quantity, it is then multiplied by $R_{u} / D$ to obtain the spring constant $k_{v 0.33}$ of the model, and this quantity is expected to represent the pile stiffness under Serviceability Limit State conditions.

The pile stiffness according to pile static tests and the secant point on the Weibull curve are presented in Table 5.

Table 5. Pile stiffness according to pile static tests and secant point on the Weibull curve

\begin{tabular}{c|c|c|c}
\hline Pile No. & $k_{s}, \mathrm{MN} / \mathrm{m}$ & $s / D, \%$ & $s, \mathrm{~mm}$ \\
\hline 1 & 132.3 & 0.640 & 2.43 \\
\hline 2 & 157.5 & 0.658 & 2.50 \\
\hline
\end{tabular}

\subsection{Spring stiffness estimation from the load bearing capacity calculation using the geotechnical data}

When calculating the characteristic values of the pile of ground bearing capacity according to the German Code DIN 1054 (Smoltczyk 2003) methodology, the bearing capacity components are distinguished as the base bearing capacity and shift friction. Also, this procedure is different from others in the case of the final output, the curve of the pile load and settlement, which helps us to judge the pile base work (Elsamee 2012). The load - settlement diagrams of both piles are presented in Figure 8 with an emphasis on the components of base and shaft resistance. The limiting settlement for the mobilization of the shaft resistance $R_{s, k}\left(s_{s g}\right)(\mathrm{MN})$ in bored (also CFA) piles is (Smoltczyk 2003):

$$
s_{s g}=0.50 R_{s, k}\left(s_{s g}\right)+0.50 \leq 3.00 \mathrm{~cm} .
$$

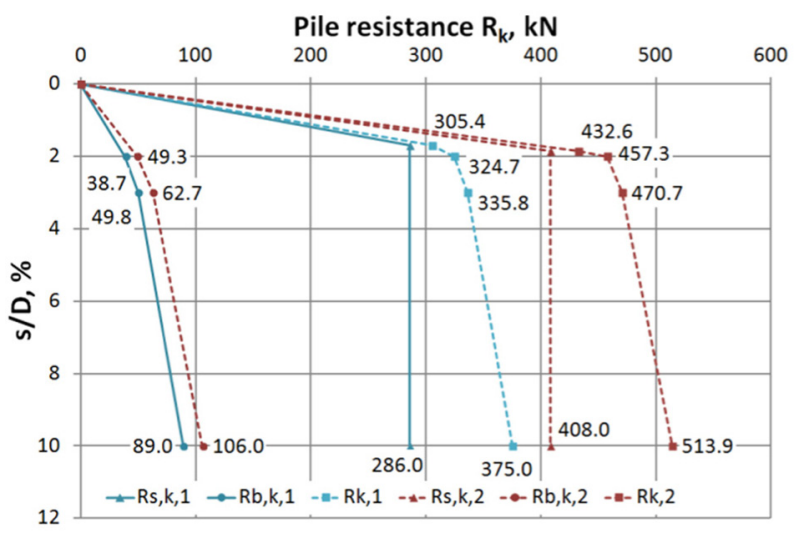

Fig. 8. Load bearing capacity according to the German Code DIN 1054 (2010)

The pile spring stiffness can be calculated following the idea of a pile working in the elastic stage to settlements mobilizing shift friction (Table 6).

It can be seen that both, the ultimate resistance and the pile stiffness obtained from the test (Tables 2, 5 and 6) 
are significantly higher than those derived by DIN 1054 (2010) (Figs 3 and 8) (Comodromos et al. 2003, 2009).

Table 6. Pile stiffness from the pile load test in the elastic stage

\begin{tabular}{c|c|c|c}
\hline Pile No. & $\mathrm{k}_{\mathrm{s}}, \mathrm{MN} / \mathrm{m}$ & $\mathrm{s} / \mathrm{D}, \%$ & $\mathrm{~s}_{\mathrm{sg}}, \mathrm{mm}$ \\
\hline 1 & 47.5 & 1.69 & 6.43 \\
2 & 61.5 & 1.85 & 7.04 \\
\hline
\end{tabular}

The load where the shift friction is mobilized may be accepted as a safe load. Using Eqn (1), the pile stiffness values are calculated and presented in Table 7 .

Table 7. Pile stiffness obtained from the analytical load settlements' curve according to the German Code DIN 1054 (2010)

\begin{tabular}{c|c|c|c|c|c}
\hline \multicolumn{2}{l|}{} & \multicolumn{3}{c}{$\mathrm{ks}, \mathrm{MN} / \mathrm{m}$} \\
\hline $\begin{array}{c}\text { Pile } \\
\text { No. }\end{array}$ & $\begin{array}{c}R_{c, k} \text { as safe } \\
\text { load kN }\end{array}$ & $\begin{array}{c}s_{s g} / D, \\
\%\end{array}$ & $\begin{array}{c}1 \text { secant, } \\
s=8 \mathrm{~mm}\end{array}$ & $\begin{array}{c}2 \text { secant, } \\
s=10 \mathrm{~mm}\end{array}$ & $\begin{array}{c}3 \text { secant, } \\
s=12 \mathrm{~mm}\end{array}$ \\
\hline 1 & 305.4 & 1.69 & 57.3 & 45.8 & 38.2 \\
2 & 432.6 & 1.85 & 81.1 & 64.9 & 54.1 \\
\hline
\end{tabular}

All calculated pile stiffness values are presented in Table 8 . The highest stiffness from all the calculations is obtained by using the Weibull curve where elastic work is taken only by $0.33 R / R_{u}$ ratio, when it could be done by (0.5-0.6) $R / R_{u}$ (Cheng 2011). The minimum stiffness (Table 7) is obtained using DIN 1054 (2010) load - the settlements curve of the pile:

$$
k_{s}=\frac{1,5 R_{c, k}\left(s_{s g}\right)}{s_{\max }},
$$

where "safe load" is $R_{c, k},\left(s_{s g}\right)$ - pile bearing capacity, when the shaft resistance is mobilized, $s_{\max }$ - pile settlement is equal to $12 \mathrm{~mm}$.

Relative settlements of the piles $s_{s c} / D$, under which the stiffness characterizing a secant is crossing pile load the relative settlement's curve, obtained from the pile static test, are presented in Table 8.

\section{Influence of pile settlements on the slab behaviour}

Behaviour of the floor slab depends on its load values (Concrete Society 2003), the layout and stiffness of the piles, and the thickness of the slab (Shadravan et al. 2015).

The investigation of a floor slab fragment of $40 \times 40$ meters was carried out. The finite element mesh was $250 \times 250 \mathrm{~mm}$. The thickness of the slab was $220 \mathrm{~mm}$. The slab thickness was selected to meet the slab punching requirements (Sagaseta et al. 2014) and according to preliminary calculations, which show the acceptable intensity of the reinforcement (STR 2.05.05:2005). The characteristic load of the slab was $50 \mathrm{kN} / \mathrm{m}^{2}$ (with the load reliability coefficient of 1.3 ).

Piles were arranged at $2.5 \times 2.5$ meters in the grid (Fig. 9). At the edges, piles were spaced every 5 meters. Such an arrangement of piles has been selected in order to achieve similar support reactions for all piles. According to such pile arrangement, all performed calculations showed that the value of the vertical load on the edge piles was $10-20 \%$ less.

The concrete strength class of the floor slab was $\mathrm{C} 25 / 30$. The crack width limitations were 0.2 and $0.1 \mathrm{~mm}$

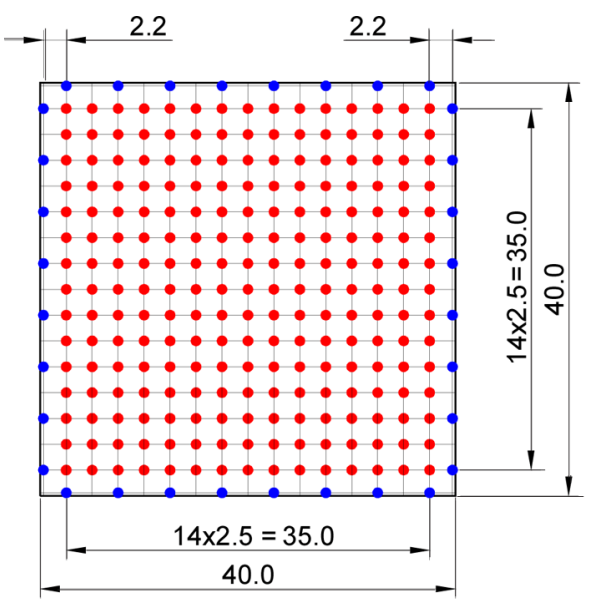

Fig. 9. Geometry of the slab and the arrangement of piles

Table 8. Calculated pile stiffness values and relative settlements $s_{s c} / D$ obtained from the pile static test

\begin{tabular}{|c|c|c|c|c|c|}
\hline \multirow{2}{*}{\multicolumn{2}{|c|}{$\begin{array}{l}\text { Calculated method of the pile stiffness } \\
\qquad k_{s}, \mathrm{MN} / \mathrm{m}\end{array}$}} & \multicolumn{2}{|l|}{ Pile 1} & \multicolumn{2}{|l|}{ Pile 2} \\
\hline & & $s_{s c} / D, \%$ & $k_{s}, \mathrm{MN} / \mathrm{m}$ & $s_{s c} / D, \%$ & \\
\hline \multirow{3}{*}{ Directly from the pile test then } & $s=8 \mathrm{~mm}$ & 100.9 & 1.04 & 124.9 & 0,97 \\
\hline & $s=10 \mathrm{~mm}$ & 80.7 & 1.54 & 99.9 & 1.49 \\
\hline & $s=12 \mathrm{~mm}$ & 67.3 & 2.13 & 83.2 & 2.08 \\
\hline \multicolumn{2}{|l|}{ Using the Weibull curve } & 132.3 & 0.65 & 157.5 & 0.61 \\
\hline From pile test then & $s=s_{s g}$ & 47.5 & 3.68 & 61.5 & 3.32 \\
\hline \multirow{3}{*}{$\begin{array}{l}\text { From analytical load settlements' curve } \\
\text { according to DIN } 1054 \text { (2010) }\end{array}$} & $s=8 \mathrm{~mm}$ & 57.3 & 2.74 & 81.1 & 2.17 \\
\hline & $s=10 \mathrm{~mm}$ & 45.8 & 3.85 & 64.9 & 3.09 \\
\hline & $s=12 \mathrm{~mm}$ & 38.2 & 4.89 & 54.1 & 3.94 \\
\hline
\end{tabular}


for the short-term and long-term cracks. The high lift trucks up to 6 meters were to be used on the floor slab. For such a situation, flatness tolerance requirements of the slab had to be satisfied (Table 9) (DIN 15185 1991). The non-compliance with these requirements could cause an overturn of a lift truck when the load is lifted.

Table 9. Flatness tolerances across and along the driving track for a lift truck of the height of $\leq 6.0 \mathrm{~m}$

\begin{tabular}{c|c|c|c}
\hline \multicolumn{4}{c}{ Truck width $S$} \\
\hline$S \leq 1.0$ & $1<S \leq 1.5$ & $1.5<S \leq 2.0$ & $2.0<S \leq 2.5$ \\
\hline $2.0 \mathrm{~mm}$ & $2.5 \mathrm{~mm}$ & $3.0 \mathrm{~mm}$ & $3.5 \mathrm{~mm}$ \\
\hline \multicolumn{4}{c}{ Truck length $S_{p}$} \\
\hline$S_{p} \leq 1.0$ & $S_{p} \leq 2.0$ & $S_{p} \leq 3.0$ & $S_{p} \leq 4.0$ \\
\hline $2.0 \mathrm{~mm}$ & $3.0 \mathrm{~mm}$ & $4.0 \mathrm{~mm}$ & $5.0 \mathrm{~mm}$ \\
\hline
\end{tabular}

The floor slab calculations with the different stiffness of piles have been performed. Four situations with the different stiffness of the piles have been investigated as the main cases. In three options (Case 1, 2 and 3), the stiffness of all of the piles under the slab was of the same value. There was one option (Case 4) where the majority of piles were of the same stiffness, but in one area of the slab the stiffness of six adjacent piles was increased by $20 \%$ and in the other area the stiffness of other adjacent six piles was reduced by $20 \%$. In such a way, the possibility that soils could become different was modelled. The results have shown a varied impact of the different stiffness of the piles on the slab reinforcement and behaviour.

\section{Case 1}

In this case, the stiffness of all piles was $47.5 \mathrm{MN} / \mathrm{m}$ (Table 6, Pile No. 1). Calculation results showed that the bottom of the floor slab had to be reinforced by using 10/10/200/200 S500 reinforcing grid. The upper part had to be reinforced by using 12/12/100/100 S500 reinforcing grid. Due to the larger distance between the piles at slab edges, additional reinforcement at slab edges was needed.

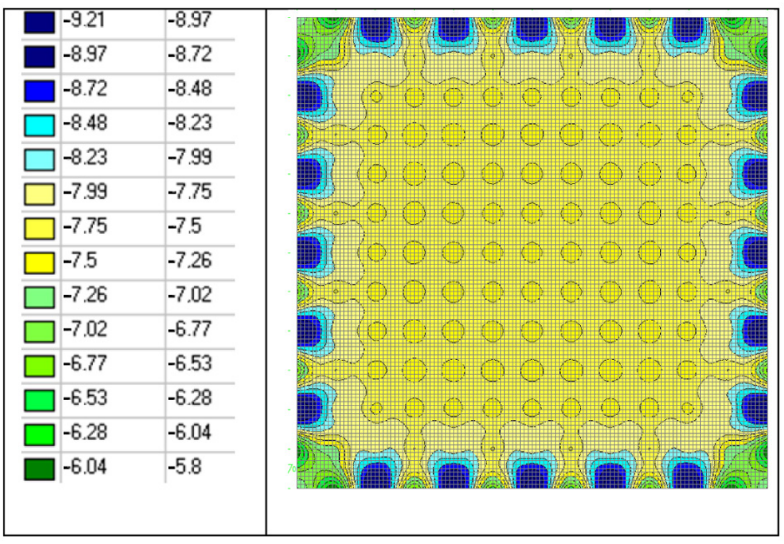

Fig. 10. Settlements of the slab (mm). Stiffness of the piles $47.5 \mathrm{MN} / \mathrm{m}$
Settlements of the slab in this case varied from 5.8 to $9.21 \mathrm{~mm}$ (Fig. 10). The stiffness of all piles was of the same value. Therefore, settlements of less-loaded piles were smaller. The flatness tolerances requirements have been satisfied (Table 9) irrespective of the direction, in which a lift truck would drive.

\section{Case 2}

It is a case, the pile stiffness was $132.3 \mathrm{MN} / \mathrm{m}$ (Table 5, Pile No 1). The research results showed that the bottom of the floor slab had to be reinforced by using 10/10/200/200 S500 reinforcing grid. The upper part had to be reinforced by using 12/12/100/100 S500 reinforcing grid. Due to the larger distance between the piles at slab edges, additional reinforcement at slab edges was needed. Reinforcement of the slab was similar to Case 1. Minor differences appeared at the edges of the slabs. Differences had been caused by lower settlement differences between the piles as in comparison to Case 1 .

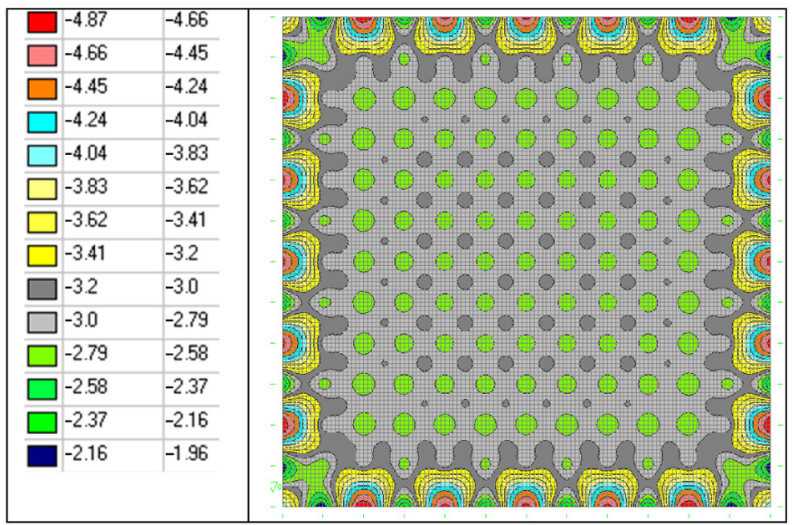

Fig. 11. Settlements of the slab (mm). Stiffness of the piles 132.3 MN/m

In this case, settlements of the slab varied depending on characteristic loads from 1.96 to $4.87 \mathrm{~mm}$ (Fig. 11). The stiffness of all piles was of the same value. Therefore, settlements of less loaded piles were smaller. The flatness tolerance requirements have been satisfied (Table 9), irrespective of the direction, in which a lift truck would drive.

\section{Case 3}

In this case, the stiffness of the piles was $80.73 \mathrm{MN} / \mathrm{m}$ (Table 2, Pile No 1, Curve 2). The study results showed that the bottom of the floor slab had to be reinforced by using 10/10/200/200 S500 reinforcing grid. The upper part had to be reinforced by using 12/12/100/100 S500 reinforcing grid. Due to a larger distance between the piles at slab edges, an additional reinforcement at the slab edges was needed. The reinforcement of the slab was similar that of Case 1 and Case 2. Minor differences have been detected at the edges of the slabs. The differences have been caused by lower settlement differences between the piles as in comparison to Case 1 and larger settlement differences between the piles as in comparison to Case 2. 


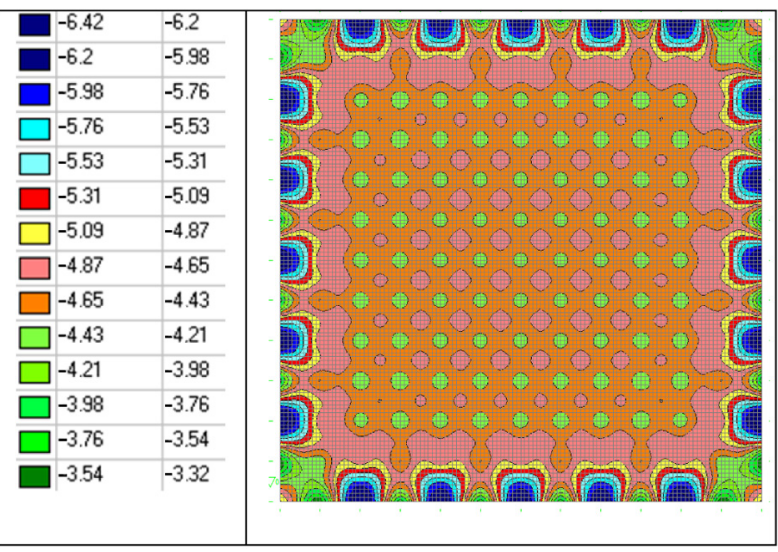

Fig. 12. Settlements of the slab (mm). Stiffness of the piles $80.73 \mathrm{MN} / \mathrm{m}$

Settlements of the slab varied from 3.32 to $6.42 \mathrm{~mm}$ (Fig. 12). In this Case, the settlements of the slab were smaller than in Case 1 and larger than in Case 2. The stiffness of all piles was of the same value. Therefore, the settlements of less loaded piles were smaller. The flatness tolerance requirements have been satisfied (Table 9), irrespective of the direction, in which a lift truck would drive.

Table 10. Comparison of calculation results

\begin{tabular}{l|l|l|l}
\hline & Case 1 & Case 2 & Case 3 \\
\hline The stiffness of all piles, MN/m & 47.5 & 132.3 & 80.73 \\
\hline $\begin{array}{l}\text { The bottom of the middle part of } \\
\text { the floor slab must be reinforced }\end{array}$ & $10 / 10 / 200 / 200 \mathrm{~S} 500$ \\
\hline $\begin{array}{l}\text { The upper part of the middle } \\
\text { part of the floor slab must be } \\
\text { reinforced }\end{array}$ & $12 / 12 / 100 / 100 \mathrm{~S} 500$ \\
\hline Settlements of the slab, mm & $\begin{array}{l}5.80 \ldots \\
9.21\end{array}$ & $\begin{array}{l}\text { 1.96 ... } \\
4.87\end{array}$ & $\begin{array}{l}3.32 \ldots \\
6.42\end{array}$ \\
\hline Flatness tolerance requirements & \multicolumn{3}{|l}{ satisfied } \\
\hline
\end{tabular}

As Table 10 shows, the difference in slab settlements in all three cases from the geotechnical point of view was insignificant. Also, the reinforcement was the same in all cases. Additional reinforcement was needed only at the edges of the slab in all cases.

\section{Case 4}

In this case, the stiffness of the majority of piles was $47.5 \mathrm{MN} / \mathrm{m}$ or $132.2 \mathrm{MN} / \mathrm{m}$. In one area (Fig. 13), the slab stiffness of six piles was increased by 20,30 or $40 \%$; and in the other area, the stiffness of six piles was reduced by 20,30 or $40 \%$. In the case of the slab with the $47.5 \mathrm{MN} / \mathrm{m}$ stiffness of the majority of piles and the variance of the stiffness of $\pm 20 \%$, the settlements were from 5.8 to $9.26 \mathrm{~mm}$ (Fig. 14). Figure 14 highlights the areas in the middle part of the slab, where the settlements were greater and lower compared with the neighbouring areas and the same areas as in Case 1. The flatness toler-

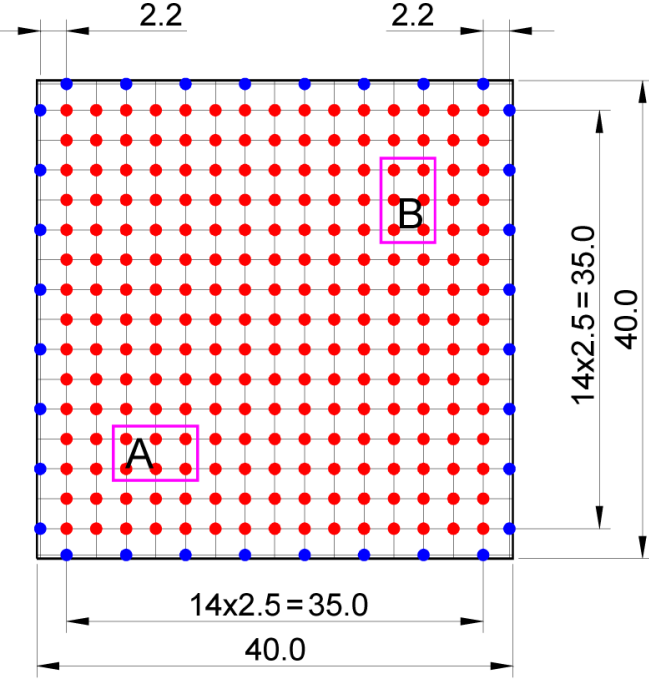

Fig. 13. Stiffness of the piles are different: area A with 20, 30 or $40 \%$ higher stiffness of piles; area B with 20,30 or $40 \%$ lower stiffness of piles

ance requirements have been satisfied (Table 8), irrespective of the direction, in which a lift truck would drive.

The main and essential difference in pile stiffness changes has become apparent while comparing the reinforcement of the slab. The calculation results of all previous cases showed that the bottom of the floor slab had to be reinforced by using 10/10/200/200 S500 reinforcing grid, and the upper part had to be reinforced by using 12/12/100/100 S500 reinforcing grid. Additional reinforcement was needed not only at the edges of the slab.

The different stiffness values/settlements of the piles in the middle part of the slab caused the redistribution of internal forces in the slab; therefore; a need for additional reinforcement in deformed zones and areas around them (Figs 15 and 16) has emerged. Generally, in is impossible to know which pile will be more or less stiff; therefore, such possibility should be evaluated, and additional reinforcement used if needed.

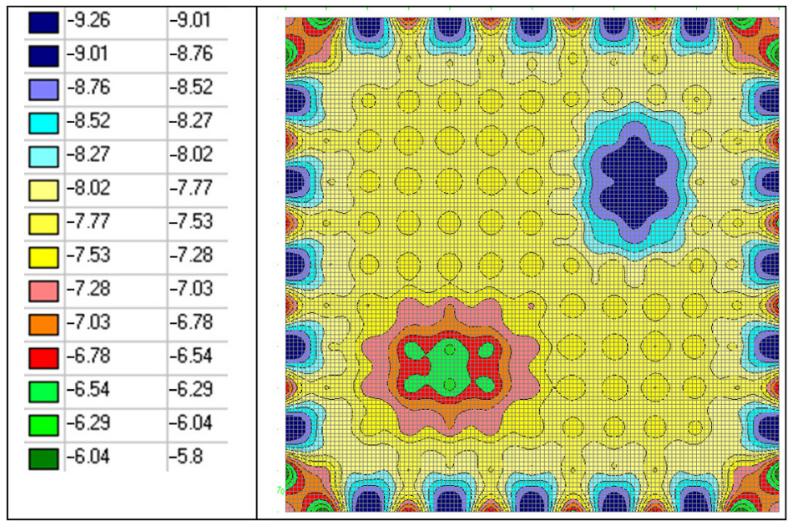

Fig. 14. Settlements of the slab $(\mathrm{mm})$. The majority of piles are $47.5 \mathrm{MN} / \mathrm{m}$; area A with pile stiffness of $57.0 \mathrm{MN} / \mathrm{m}$, area $B$ with pile stiffness of $38.0 \mathrm{MN} / \mathrm{m}$ 


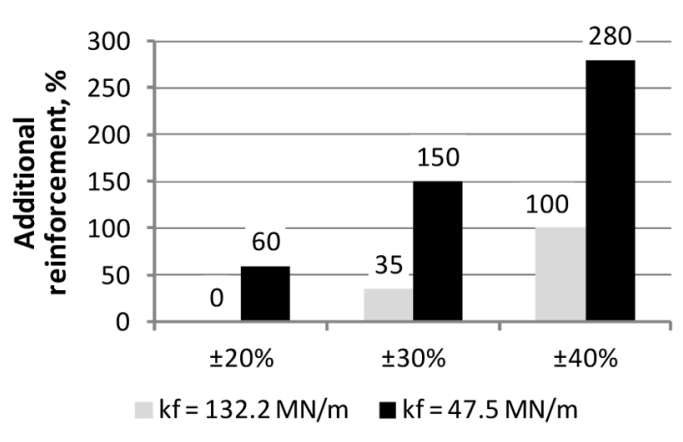

Fig. 15. Additional reinforcement in the bottom of the floor slab

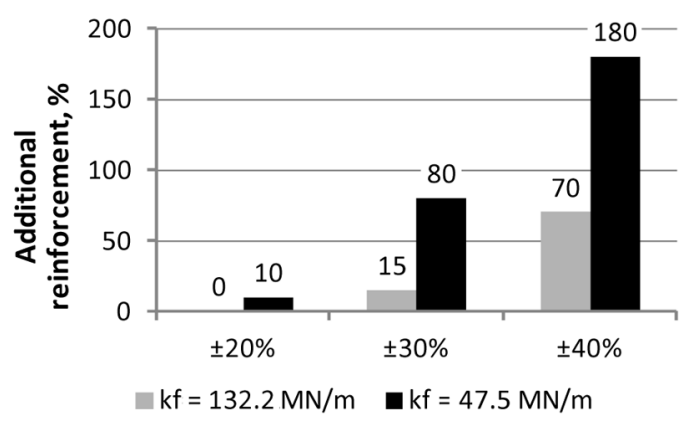

Fig. 16. Additional reinforcement in the upper part of the floor slab

Moreover, finalizing the calculations it could be stated that different stiffness of the piles, just as different loading on the slab in neighbouring areas, could cause differences in settlements. When the piles are stiffer, the values of settlements are smaller as well as differences of settlements of neighbouring areas. Therefore, in all cases, stiffer piles are preferable and advantageous. However, calculations with smaller pile stiffness are safe and reasonable for preliminary design.

\section{Assumptions proposed for the calculation of the slab on the piles}

Since the design of plates on piles usually has no static pile testing results, it is suggested to indicate the pile stiffness through the pile limiting settlement for the mobilization of the shaft resistance working in the elastic stage. Such pile stiffness may be determined using the DIN1054 methodology for the assessment of the pile base bearing capacity (Table 6). The stiffness determined in this way is lower than that obtained experimentally (Tables 2 and 5). Such assessment method will enable the prediction of the pile stiffness under different geotechnical conditions because the calculation estimates soil characteristics (Smoltczyk 2003).

Taking into consideration the change in soil properties and the possibility of the different stiffness of piles under the plate, an additional reinforcement of the plate may be required (Figs 15 and 16).

\section{Results and conclusions}

1. The pile stiffness coefficient can be determined from the pile static tests, evaluation of a particular project for the "safe load" and settlements. The pile stiffness obtained using the Weibull curve is much greater than using the other three methods including the pile test method; therefore, this method is not sufficiently effective or suitable for this type of slab calculations.

2. When there is no static pile testing, pile stiffness may be taken from the load-settlement curve obtained from DIN 1054 (2010). The stiffness determined in this way is lower than that obtained experimentally. Therefore, when the ground under the plate is varied and different, the plate must be additionally reinforced.

3. Piles under the floor slab have to be located properly to achieve settlements of all of the piles that would be as similar as possible. It can be achieved using the idea that each pile must be of even stiffness. In this way, not only settlements of the slab areas become similar, but also, slab reinforcement intensity in all areas of the slab is much more even, with no significant concentrations of internal forces.

4. Usually, characteristics of soils change to a lesser or greater extent. Thus, the stiffness of the piles differs as well. Calculation results have shown that additional reinforcement of the slab is needed. Therefore, the possibility of different settlements should be evaluated.

5. When characteristics of the soils are very similar, and loads on the piles are equal, the stiffness of the piles does not affect the reinforcement of the slab. Slab reinforcement is equal and does not depend on the stiffness value of the piles. This conclusion is valid when loadings on the slab are uniform.

\section{References}

Basile, F. 2015. Non-linear analysis of vertically loaded piled rafts, Computers and Geotechnics 63: 73-82. http://dx.doi.org/10.1016/j.compgeo.2014.08.011

Cheng, Z. 2011. Prediction and measurement of settlement of a piled raft foundation over thick soft ground, The Electronic Journal of Geotechnical Engineering 16: 125-136.

Comodromos, E. M.; Papadopoulou, M. C.; Rentzeperis, M. C. 2009 Pile foundation analysis and design using experimental data and 3-D numerical analysis, Computers and Geotechnics 36(5): 819-836.

http://dx.doi.org/10.1016/j.compgeo.2009.01.011

Comodromos, E. M.; Anagnostopoulos, C. T.; Georgiadis, M. K. 2003. Numerical assessment of axial pile group response based on load test, Computers and Geotechnics 30(6): 505-515.

http://dx.doi.org/10.1016/S0266-352X(03)00017-X

Concrete Society. 2003. Concrete industrial ground floors $-a$ guide to design and construction. Concrete Society Technical Report No. 34.

DIN 1054. Baugrund - Sicherheitsnachweise im Erd - und Grundbau, 2010.

DIN 15185. Lagersysteme mit leitliniengeführten Flurförderzeugen, 1991. 
Elsamee, W. N. A. 2012. Evaluation of the ultimate capacity of friction, Piles Engineering 4: 778-789. http://dx.doi.org/10.4236/eng.2012.411100

EN 1997-1. Eurocode 7: Geotechnical design - part 1: general rules. Authority: The European Union Per Regulation 305/2011, Directive 98/34/EC, Directive 2004/18/ EC], 2004.

Fioravante, V. 2002. On the shaft friction modelling of nondisplacement piles in sand, Soils and Foundations 42(2): 23-33. http://dx.doi.org/10.3208/sandf.42.2 23

Gusev, G. N.; Tashkinov, A. A. 2012. Numerical modelling of force interaction between slab - pile foundations and soil massif, Vychislitel'naya mekhanika sploshnykh sred 5(3): $359-363$

IS 2911-1-4 Code of practice for design and construction of pile foundations, Part 1: Concrete piles, Section 4: Bored precast concrete piles [CED 43: Soil and Foundation Engineering]. Bureau of Indian Standards. 30 p.

Jeong, S.; Cho, J. 2014. Proposed nonlinear 3-D analytical method for piled raft foundations, Computers and Geotechnics 59: 112-126. http://dx.doi.org/10.1016/j.compgeo.2014.02.009

Katzenbach, R.; Arslan, U.; Moormann, C. 2000. Piled raft foundation projects in Germany, in J. A. Hemsley (Ed.). Design applications of raft foundations. London: Thomas Telford, 323-392. http://dx.doi.org/10.1680/daorf.27657.0013

Lee, J.; Park, D.; Park, D.; Park, K. 2015. Estimation of loadsharing ratios for piled rafts in sands that includes interaction effects, Computers and Geotechnics 63: 306-314. http://dx.doi.org/10.1016/j.compgeo.2014.10.014

Mendonça, A. V.; Paiva, J. B. 2003. An elastostatic FEM/BEM analysis of vertically loaded raft and piled raft foundation, Engineering Analysis with Boundary Elements 27(9): 919933. http://dx.doi.org/10.1016/S0955-7997(03)00061-4

Poulos, H. G. 2001. Piled raft foundations: design and applications, Geotechnique 51(2): 95-113. http://dx.doi.org/10.1680/geot.2001.51.2.95
Poulos, H. G. 1994. An approximate numerical analysis of pile raft interaction, International Journal for Numeral and Analytical Methods in Geomechanics 18: 73-92. http://dx.doi.org/10.1002/nag.1610180202

Ripunjoy, D. 2014. Different analysis methods of piled rafts, International Journal of Engineering Technology, Management and Applied Sciences 2(4): 158-167.

Sagaseta, J.; Tassinari, J.; Fernandez Ruiz, M.; Muttoni, A. 2014. Punching of flat slabs supported on rectangular columns, Engineering Structures 77(15): 17-33. http://dx.doi.org/10.1016/j.engstruct.2014.07.007

Samofalov, M.; Papinigis, V.; Tūnaitis, M. 2015. Mechanical state analysis of different variants of piled rafts, The Baltic Journal of Road and Bridge Engineering 10(1): 1-10. http://dx.doi.org/10.3846/bjrbe.2015.01

Shadravan, S.; Ramseyer, C.; Kang, T. H.-K. 2015. A long term restrained shrinkage study of concrete slabs on ground, Engineering Structures 102(1): 258-265. http://dx.doi.org/10.1016/j.engstruct.2015.08.018

Smoltczyk, U. (Ed.). 2003. Geotechnical engineering handbook. Volume 3: Elements and structures. Wiley.

STR 2.05.05:2005. Betoniniu ir gelžbetoniniu konstrukciju projektavimas. Statybos techninis reglamentas [Concrete and reinforced concrete structures. Construction Technical Regulation] (in Lithuanian).

Takagi, K.; Chung, K. L. T.; Honjo, Y.; Kunimasa, Y. 2007. Determination of vertical spring constants of a single pile based on statistical analysis of pile loading database, Journal Japan Society of Civil Engineers 53A: 208-217.

Technical Committee TC18 on Piled Foundations. 2001. Methods of analysis of piled raft foundations. A Report Prepared on Behalf of Technical Committee TC18 on Piled Foundations. 46 p.

Wulandari, P. S.; Tjandra, D. 2015 Analysis of piled raft foundation on soft soil using PLAXIS 2D, Procedia Engineering 125: 363-367.

http://dx.doi.org/10.1016/j.proeng.2015.11.083

Kęstutis URBONAS. Dr Assoc. Prof. of Steel and Timber Department. Vilnius Gediminas Technical University. Lithuania. Fields of research: structural calculations, FE method, relationship between ground and structures, steel structures, semi-rigid steel joints.

Danutė SLIŽYTĖ. Dr, Assoc. Prof. of the Geotechnical Department of Vilnius Gediminas Technical University. Fields of research: foundation underpinning, relationship between ground and structures, estimation of soil mechanical properties, pile foundation.

Rimantas MACKEVIČIUS. Dr, Assoc. Prof. of the Geotechnical Department of Vilnius Gediminas Technical University. Fields of research: soil stabilization, foundation underpinning, estimation of soil mechanical properties, pile foundation. 